
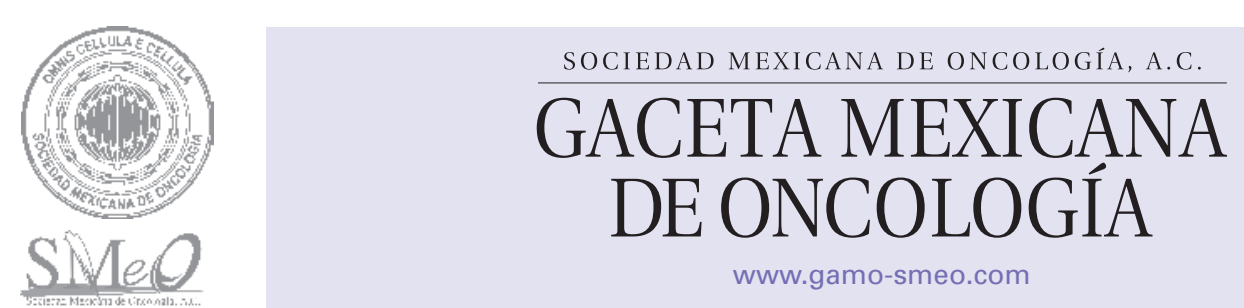

www.gamo-smeo.com

ORIGINAL ARTICLE

\title{
Pediatric cancer distribution in the State of Puebla
}

\section{María José Muñoz-Pérez ${ }^{1,2}$, Stephania Casco $^{1,2}$ and Elena Soto-Vega ${ }^{1,3 *}$}

${ }^{1}$ Center for Oncological Research Una Nueva Esperanza A.B.P.; ${ }^{2}$ Faculty of Medicine, Universidad Popular Autonoma del Estado de Puebla; ${ }^{3}$ Faculty of Medicine, Universidad Anahuac Puebla, Puebla, Mexico

Received for publication: 1 October 2016; accepted for publication: 25 February 2017

Available online: 6 November 2017

\section{KEY WORDS}

Pediatric cancer;

Puebla;

Acute lymphoblastic

leukemia
Abstract Introduction: At present, in the world, there are approximately 360,000 children with cancer, many of them without social security in developing countries. Materials and methods: In this study, a retrospective analysis was performed of medical records from subjects youngero than 21 years of age with cancer who live in extreme poverty and lack social security. The main purpose was to identify a pediatric cancer distribution pattern in the state of Puebla, Mexico, as well as sociodemographic characteristics and main types and incidences of disease. Results: A total of 406 medical records were reviewed; 4 years was the age with the highest rate of diagnosis, and male gender was predominantly affected. The most commonly found malignancy was acute lymphoblastic leukemia, followed by germ cell tumors and acute myeloblastic leukemia, with histiocytosis abnormal behavior also being found. Conclusions: These data are useful for health systems to detect municipalities with higher incidence and this way creates alerts for earlier diagnosis of the disease and thereby increases children survival: (creativecommons.org/licenses/by-nc-nd/4.0/).

*E-mail for correspondence: elenasoto_74@hotmail.com (E. Soto-Vega) 


\section{INTRODUCTION}

Cancer is one of the five leading causes of death worldwide. The World Health Organization estimates that cancer-associated deaths will account for $70 \%$ of overall mortality in developing countries by the year $2030^{1}$. In the world, there are approximately 12 million of people diagnosed with cancer, and nearly $3 \%$ are children ${ }^{2}$.

Pediatric cancer is a problem in developing countries due to its high incidence and health systems' limited resources, which delays diagnosis and hinders adequate management of these patients. In 2012, a higher incidence of pediatric cancer was estimated in developed than in developing countries, with 147,000 cases/year and a higher mortality rate, which is associated with the fact that two-thirds of children and adolescents with a malignancy do not receive opportune diagnosis and adequate multidisciplinary treatment ${ }^{3}$. In Mexico, only $20 \%$ of this population has social security; the rest has to cover expenses with its income, with most part of this population having to travel from its communities to be able to receive treatment ${ }^{4}$.

Pediatric cancer is the second cause of death in people younger than 20 years. It comprises a group of diseases with particular characteristics that differentiate them from adult diseases such as anatomical localization, histological pattern, and different behavior. The most common pediatric neoplasms are leukemia (30-50\%), lymphomas (17.1\%), and central nervous system tumors $(11.9 \%)^{4}$.

In spite of advances in treatment and medicine, pediatric cancer remains a public health problem. Fajardo-Gutiérrez et al. reported that in the period between 1996 and 2007, a total of 3,238 new cases were recorded only in 5 states of the Mexican Republic, with the most commonly recorded neoplasms being leukemia (46.1\%), central nervous system tumors $(12.0 \%)$, and lymphomas $(10.8 \%)^{5}$. Health system in Mexico is divided into public and private sectors. The public sector provides care to two populations: With social security and without social security through the people's health insurance (Seguro popular), with the latter being the most vulnerable population of the country from the socioeconomic point of view.

According to data of the last population census by the National Institute of Statistics, Geography and Informatics (Instituto Nacional de Estadística, Geografía e Informática [INEGI]), in the state of Puebla there were 2,315,923 people younger than 20 years of age in the year 2010. The Ministry of Health in Mexico repots an annual average of 122 cases of pediatric cancer per million population of 0-20 years of age $^{2,6}$. The 2008-2012 bulletin of cancer information on children and adolescents with cancer reports that, in the state of Puebla, the three main neoplasms in people younger than 18 years are: Leukemia (52\%), lymphomas and reticuloendothelial neoplasms $(12 \%)$, and germ cell neoplasms $(9 \%)^{7}$. The purpose of this study was to identify a geographic pattern of pediatric cancer in the state of Puebla, as well as some sociodemographic and clinical characteristics.

\section{MATERIALS AND METHODS}

A retrospective study was conducted with data of 406 children who were beneficiaries of the Una Nueva Esperanza
A.B.P. foundation in Puebla. Sociodemographic data were obtained of children attended to during the 2005-2010 period. Since 1999, the foundation provides care to low-income children with cancer who lack social security. Since its opening and until 2010 its population has been increasing every year, with 71 beneficiaries per year being attended to, with this figure increasing from 2010 to 2015 to a total of 110 beneficiaries per year.

For the analysis, the state of Puebla was divided ac cording to the seven socioeconomic regions managed by the National Institute for Federalism and Municipal Development (INAFED - Instituto Nacional para el Fede ralismo y el Desarrollo Municipal), which together com prise 217 municipalities, as follows: I Huauchinango/ह Sierra Norte, II Teziutlán/Sierra Nororiental, III Ciudad Serdán, IV Angelópolis/San Pedro Cholula, V Valle de Atlixco and Matamoros, VI Izúcar de Matamoros/Mixteca, and VII Tehuacán/Sierra Negra (Fig. 1). Each patient was located according to his/her municipality at any of these regions.

To calculate the incidence, data of the 2010 INEGI population and housing census were used. To obtain the popula-y tion data by age and gender, the request was made to INEGE through the citizen transparency portal, and only population attended to at the foundation until 2010 could, therefore, be analyzed.

Incidence is defined as the number of new cases of a disease occurring in a specific period of time, which is calculated with the formula: Incidence rate $=$ (Number of cases $\times 100,000$ or 1000,000$) /$ Total population. The formula was applied depending on the number of total inhabitants of the region. This information was used to calculate the number of children expected per economic region.

Data obtained from each patient's medical record were captured in a Microsoft Excel 2010 spreadsheet.

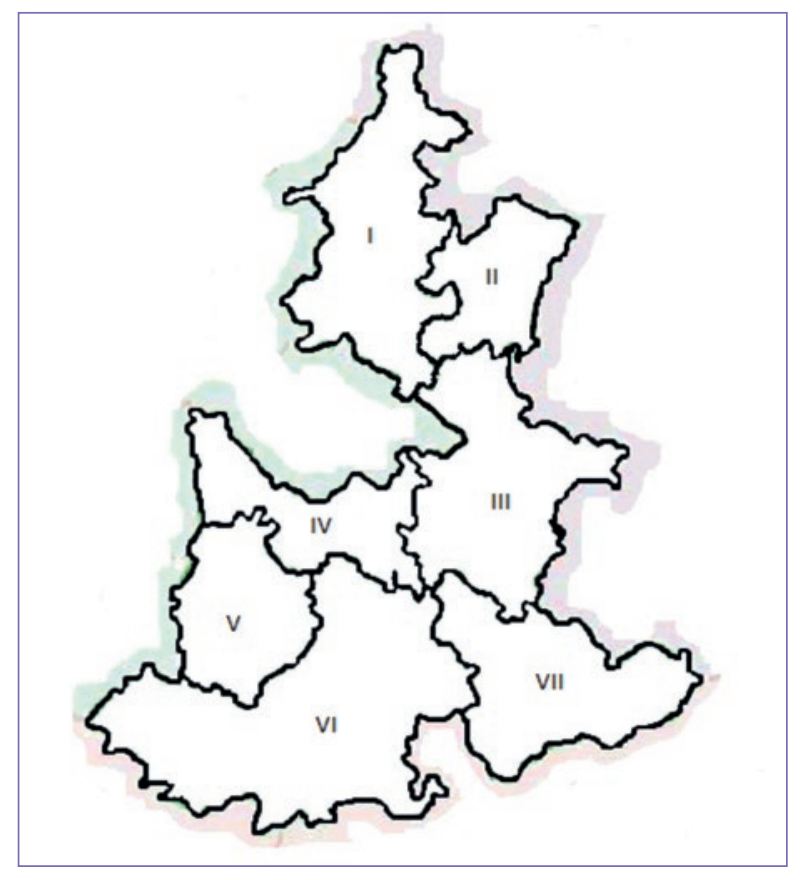

Figure 1. Socioeconomic regions of the state of Puebla according to the National Institute for Federalism and Municipal Development. 
Table 1. Population younger than 20 years, expected incidence of neoplasms, number of minors without social security attended to during 5 years and incidence of population attended to by UNE per year

\begin{tabular}{|c|c|c|c|}
\hline Region & $\begin{array}{l}\text { Total population younger } \\
\text { than } 20 \text { years }\end{array}$ & $\begin{array}{l}\text { Cases expected } \\
\text { per year }\end{array}$ & $\begin{array}{c}\text { Minors attended } \\
\text { to by UNE }\end{array}$ \\
\hline I. Huauchinango & 318,988 & 39 & $45(9.0)$ \\
\hline II. Teziutlán/Sierra Nororiental & 247,234 & 30 & $41(8.2)$ \\
\hline III. Ciudad Serdán/Chalchicomula de Sesma & 310,531 & 37 & $57(11.4)$ \\
\hline IV. Angelópolis/San Pedro Cholula & $1,114,998$ & 136 & $148(29.6)$ \\
\hline V. Valle de Atlixco & 171,636 & 21 & $27(5.4)$ \\
\hline VI. Izúcar de Matamoros/Mixteca & 146,063 & 18 & $34(6.8)$ \\
\hline VII. Tehuacán and Sierra Negra & 312,411 & 38 & $54(10.8)$ \\
\hline Total & $2,621,861$ & 122 & $406(81.0)$ \\
\hline
\end{tabular}

\section{RESULTS}

The geographic distribution of the 406 children with cancer was determined, and each one was assigned a geographic region within the state of Puebla. Among the seven socioeconomic regions, the most populated had larger numbers of children with cancer, except for region III (Ciudad Serdán), which was found to be the second, in percentage of children with cancer while being the fourth in children population (Table 1).

The sample was comprised by $53.69 \%$ of boys and $46.31 \%$ of girls, and cancer was, therefore, more common in the male gender; however, in regions II (Teziutián) and VI (Izúcar de Matamoros), the distribution of these percentages is inverted (Table 2).

Mean age of the sample was $7.73 \pm 4.89$ years, although the population mode was 4 years $(10.10 \%)$ at diagnosis.

The most common condition found in the children population of the state of Puebla was acute lymphoblastic leukemia (ALL) (48.02\%). The percentage of children with ALL in the state of Puebla ranges from $6.4 \%$ (region V-Atlixco) to up to $69.1 \%$ (Region IV-Angelópolis/ San Pedro Cholula) (Table 3). Among other conditions, germ cell tumors, acute myeloblastic leukemia, Hodgkin's lymphoma, among others, were found in the population (Table 4).

Region VII (Tehuacán and Sierra Negra) showed an abnormal behavior in the incidence of central nervous system tumors (astrocytomas, medulloblastomas, and anaplastic ependymomas) since these were at a second place in incidence (1.3) of neoplasms of that region with a total of $7.4 \%$ of children with cancer of this region. On the other hand, no children with central nervous system tumors were detected in region $\mathrm{V}$ (Valle de Atlixco and Matamoros).

Histiocytosis is within the five main types of cancer in 3 regions of the state (II Teziutlán/Sierra Nororiental), VI Izúcar de Matamoros/Mixteca, and VII Tehuacán/Sierra Negra), with incidence rates of $0.8 \%, 0.7 \%$, and $0.6 \%$, respectively.

\section{DISCUSSION}

The state of Puebla has a very varied geography and is a state crossed by the main mountain ranges of the country,
Table 2. Proportion by gender of children attended to by 2010

\begin{tabular}{lcc}
\hline Puebla socioeconomic region & Male (\%) & Female (\%) \\
\hline I. Huauchinango & 55.56 & 44.44 \\
II. Teziutlán/Sierra Nororiental & 41.46 & 58.54 \\
$\begin{array}{l}\text { III. Ciudad Serdán/ } \\
\text { Chalchicomula de Sesma }\end{array}$ & 52.63 & 47.37 \\
$\begin{array}{l}\text { IV. Angelópolis/San Pedro } \\
\text { Cholula }\end{array}$ & 58.78 & 41.22 \\
V. Valle de Atlixco & 59.26 & 40.74 \\
VI. Izúcar de Matamoros/ & 50.00 & 50.00 \\
Mixteca & & \\
VII. Tehuacán and Sierra Negra & 48.13 & 51.85 \\
Total & 53.69 & 46.31 \\
\hline
\end{tabular}

Table 3. Percentage of the main tumors occurring in the state of Puebla in the study population from 1999 to 2010

\begin{tabular}{lc}
\hline Condition & $\mathrm{n}(\%)$ \\
\hline Acute lymphoblastic leukemia & $195(48.02)$ \\
Germ cell tumors & $23(5.66)$ \\
Acute myeloblastic leukemia & $18(4.43)$ \\
Hodgkin's lymphoma & $15(3.69)$ \\
Wilms' tumor & $14(3.44)$ \\
Non-Hodgkin lymphoma & $8(1.97)$ \\
Central nervous system tumors & $8(1.97)$ \\
Osteosarcoma & $5(1.23)$ \\
\hline
\end{tabular}

and when analyzing it by economic regions, municipalities with similar orographic characteristics are, therefore, grouped. In 2007, Fajardo-Gutiérrez et al. published a study with 2,663 children younger than 15 years from 11 states of the Mexican Republic where ALL was the main oncologic condition, with an incidence ranging from $28.2 \%$ to $74.2 \%{ }^{5,8}$. In that study, Puebla had an incidence of $72.9 \%$ for leukemia; however, in this study, the results differ with regard to incidence, since an incidence of $8.6 \%$ was obtained in all 7 regions of the state. The population assessed in this study has different characteristics because it is a population in poverty that lacks social security. The incidence of ALL in the 
Table 4. Main conditions found by socioeconomic region

\begin{tabular}{|c|c|c|c|c|}
\hline Region & Mean age (SD) & Main conditions found & Percentage & Incidence (\%) \\
\hline I. Huauchinango & $7.2 \pm 4.7$ & $\begin{array}{l}\text { 1. ALL } \\
\text { 2. AML } \\
\text { 3. Non-Hodgkin lymphoma } \\
\text { 4. Rhabdomyosarcoma Hodgkin's lymphoma } \\
\text { and germ cell tumors }\end{array}$ & $\begin{array}{c}52.27 \% \\
9.09 \% \\
6.82 \% \\
4.55 \% \text { each }\end{array}$ & $\begin{array}{c}7.21 \\
1.25 \\
0.94 \\
0.63 \text { each }\end{array}$ \\
\hline $\begin{array}{l}\text { II. Teziutlán/Sierra } \\
\text { Nororiental }\end{array}$ & $8 \pm 4.9$ & $\begin{array}{l}\text { 1. ALL } \\
\text { 2. Wilms' tumor germ cell tumors } \\
\text { 3. AML Hodgkin's lymphoma, histiocytosis } \\
\text { 4. Osteosarcoma, retinoblastoma, CNS } \\
\text { tumors sarcomas }\end{array}$ & $\begin{array}{c}41.46 \% \\
7.32 \% \text { each } \\
4.88 \% \text { each } \\
2.44 \% \text { each }\end{array}$ & $\begin{array}{l}6.90 \\
1.2 \text { each } \\
0.8 \text { each } \\
0.4 \text { each }\end{array}$ \\
\hline $\begin{array}{l}\text { III. Ciudad Serdan/ } \\
\text { Chalchicomula de } \\
\text { Sesma }\end{array}$ & 8.2 years \pm 5.7 & $\begin{array}{l}\text { 1. ALL } \\
\text { 2. AML, Non-Hodgkin lymphoma } \\
\text { 3. Histiocytosis, germ cell tumors } \\
\text { 4. Hybrid leukemia, Hodgkin's lymphoma, } \\
\text { Wilms' tumor, osteosarcoma, and } \\
\text { retinoblastoma }\end{array}$ & $\begin{array}{c}39.66 \% \\
6.90 \% \text { each } \\
3.45 \% \text { each } \\
1.72 \% \text { each }\end{array}$ & $\begin{array}{l}7.4 \\
1.3 \text { each } \\
0.6 \text { each } \\
0.3 \text { each }\end{array}$ \\
\hline $\begin{array}{l}\text { IV. Angelópolis/San } \\
\text { Pedro Cholula }\end{array}$ & 8.1 years \pm 5.1 & $\begin{array}{l}\text { 1. ALL } \\
\text { 2. Germ cell tumors } \\
\text { 3. Wilms' tumor } \\
\text { 4. AML }\end{array}$ & $\begin{array}{l}52.38 \% \\
7.48 \% \\
4.08 \% \\
3.4 \%\end{array}$ & $\begin{array}{l}69.1 \\
9.9 \\
5.4 \\
4.5\end{array}$ \\
\hline V. Valle de Atlixco & 7.8 years \pm 5.8 & $\begin{array}{l}\text { 1. ALL } \\
\text { 2. Hodgkin's lymphoma, non-Hodgkin } \\
\text { lymphoma, Wilms' tumor and germ cell } \\
\text { tumors } \\
\text { 3. AML, abdominal sarcomas, Ewing's } \\
\text { sarcoma and chondrosarcomas } \\
\text { 4. Unidentified neoplasms }\end{array}$ & $\begin{array}{c}40.74 \% \\
7.41 \% \text { each } \\
3.70 \% \text { each } \\
11.11 \%\end{array}$ & $\begin{array}{l}6.4 \\
1.2 \\
0.6 \\
-\end{array}$ \\
\hline $\begin{array}{l}\text { VI. Izúcar de } \\
\text { Matamoros/Mixteca }\end{array}$ & 7.7 years \pm 5.4 & $\begin{array}{l}\text { 1. ALL } \\
\text { 2. Hodgkin's lymphoma } \\
\text { 3. Germ cell tumors } \\
\text { 4. CNS tumors }\end{array}$ & $\begin{array}{l}41.18 \% \\
11.76 \% \\
8.82 \% \\
5.88 \%\end{array}$ & $\begin{array}{l}9.6 \\
2.7 \\
2.1 \\
1.4\end{array}$ \\
\hline $\begin{array}{l}\text { VII. Tehuacán and } \\
\text { Sierra Negra }\end{array}$ & 8.3 years \pm 5.1 & $\begin{array}{l}\text { 1. ALL } \\
\text { 2. CNS tumors } \\
\text { 3. AML, histiocytosis, retinoblastoma } \\
\text { 4. Hybrid leukemia, Wilms' tumor, } \\
\text { rhabdomyosarcoma, osteosarcoma, } \\
\text { hepatoblastoma and Ewing's sarcoma }\end{array}$ & $\begin{array}{c}53.70 \% \\
7.41 \% \\
3.7 \% \text { each } \\
1.85 \% \text { each }\end{array}$ & $\begin{array}{l}9.3 \\
1.3 \\
0.6 \\
0.3\end{array}$ \\
\hline
\end{tabular}

ALL: Acute lymphoblastic leukemia; AML: Acute myeloblastic leukemia; CNS: Central nervous system, SD: Standard deviation.

state of Puebla varied according to the region from $6.9 \%$ to $69.1 \%$, with the capital city of the state having the highest incidence $^{5,8}$.

In contrast with reports in the USA literature, where the highest incidence of ALL is described to occur between 2 and 3 years of age, the present study found that the most common age of diagnosis was 4 years in the study population. The 2011 Ministry of Health epidemiological profile of cancer in children and adolescents in Mexico states that the main age range for cancer diagnosis is $10-14$ years, followed by the $5-9$ years group. However, among the groups analyzed in this study, the $0-4$ years group $(n=133)$ is at first place, while the $10-14$ years group $(n=104)$ is at third place. It is important mentioning that central nervous system tumors, identified in the study by Fajardo-Gutiérrez et al. as the second cause of children's neoplasms, was found to be the sixth cause of pediatric cancer in our population ${ }^{5,8}$.

Histiocytosis was found to be among the first five most common types of neoplasm in 3 regions of Puebla (II: Teziutlán/Sierra Nororiental, III: Ciudad Serdán, and VI: Izúcar de Matamoros/Mixteca) ${ }^{2}$. This is a finding that should be further studied, as this is not a common neoplasm in the pediatric population $^{2}$.

\section{CONCLUSION}

Cancer opportune diagnosis is an essential element for patient survival since the sooner it is detected, the probabilities for cure are higher. In Mexico, epidemiological data on pediatric cancer distribution are still limited. The data obtained in the present study will be useful for health systems and physicians, in general, to detect municipalities with higher incidence of cancer, and this way, alerts will be able to be created for earlier diagnosis of the disease and hence increase children survival, in addition, that they will contribute to national cancer epidemiology databases enrichment.

\section{DECLARATION INTEREST}

The authors declare not having any conflicts of interest. 


\section{REFERENCES}

1. Itriago L, Silva N, Cortes G. Cáncer en Chile y el mundo: Una mirada epidemiológica, presente y Futuro. Rev Med Clin Condes. 2013;24: $531-52$.

2. Secretaria de Salud. Perfil Epidemiológico del Cáncer en Niños y Adolescentes en México. México: Secretaria de Salud; 2011.

3. Rivera-Luna R, Shalkow-Klincovstein J, Velasco-Hidalgo L, et al. Descriptive epidemiology in Mexican children with cancer under an open national public health insurance program. BMC Cancer. 2014;14:790.

4. SINAVE, Orozco-Magdaleno CE. Estudio descriptivo de cáncer en niños y adolescentes en un hospital asistencial en la costa de Chiapas: 20092013. Hig Sanid Ambient. 2014;14:1223-7.
5. Fajardo-Gutiérrez A, Palma-Padilla V, Carreón-Cruz R, Mejía-Aranguré JM, et al. Incidencia general y específica de cáncer en niños derechohabientes del IMSS. Rev Med Inst Mex Seguro Soc. 2007;45:579-92.

6. INEGI. Resultados Censo de Poblacion y Vivienda. Mexico: INEGI; 2010. Available from: http://www.inegi.org.mx/est/contenidos/proyectos/ ccpv/cpv2010/Default.aspx [Downloaded on: feb 4, 2015].

7. Secretaria de Salud. Boletín de Información de Cáncer en Niñas (os) y Adolescentes con cáncer 2008 a 2012. Mexico: Secretaria de Salud; 2014. Available from: http://censia.salud.gob. $\mathrm{mx} /$ contenidos/descargas/cancer/BoletinNacionalCancer2014.pdf. [Downloaded on: feb 4 , 2015].

8. Allende-López A, Fajardo-Gutiérrez A. History of the cancer registry in Mexico. Rev Med Inst Mex Seguro Soc. 2011;49 Suppl 1:S27-32. 